\title{
Genotyping Growth Hormone-AluI Locus of Bali Cattle in Pleihari, South Kalimantan
}

\author{
Muh. Affan Mu'in \\ Faculty of Animal Science, \\ Papua University, Manokwari, West Papua \\ Jl. GunungSalju, Amban, manokwari 98314. \\ E-mail: muinunipa@gmail.com
}

Accepted: Januari 5, 2018 ; Approved: Maret 1, 2018

\begin{abstract}
The study was conducted to genotyping growth hormone-AluI (GH-AluI) locus of Bali cattle in Pleihari, South Kalimanan. Blood samples were taken from 46 Bali cattle in Pleihari, South Kalimantan. The genotyping of this locus was conducted by digested the DNA fragment of $221 \mathrm{bp}$ extended from the forth intron region (49 bp) to fifth of exon (162 bp) by AluI enzyme. The resulted indicated that the Bali cattle population in Pleihari, South Kalimantan only L alelle was found, and no found $\mathrm{V}$ alelle and other alelle in this locus. Its concluded that the $\mathrm{H}-\mathrm{Al} u \mathrm{I}$ locus of Bali cattle in Pleihari, South Kalimantan was monomorphic.
\end{abstract}

(Key Words: genotype, growth hormone gene, monomorphic, Alu-I, Bali cattle)

\begin{abstract}
Abstrak
Penelitian ini bertujuan untuk mengidentifikasi genotip dari lokus growth hormone-AluI (GH-AluI) pada populasi sapi Bali di Pleihari, Kalimantan Selatan. Sampel darah diambil dari 46 ekor sapi Bali (25 jantan dan 21 betina) di lokasi Pleihari, Kalimantan Selatan. Identifikasi genotip dari lokus ini dilakukan dengan mendigesti fragmen DNA berukuran 221 bp yang merentang dari daerah intron 4 (49 bp) hingga exon 5 (162 bp) menggunakan enzim restriksi $A l u$ I. Hasil penelitian menunjukkan bahwa lokus GH-AluI pada populasi sapi Bali di Pleihari, Kalimantan Selatan hanya memiliki satu macam alel, yaitu alel L, dan tidak ditemukan alel V atau alel lainnya pada lokus ini. Disuimpulkan bahwa lokus GH-AluI pada populasi sapi Bali di Pleihari, Kalimantan Selatan bersifat monomorfik.
\end{abstract}

Kata kunci: sapi Bali, genotip, growth hormone gene, Alu-I, monomorfik.

\section{Introduction}

Growth hormone $(\mathrm{GH})$ is the hormone which play role important in body growth control. GH or somatotrophin (STH) was protein content of 191 amino acids. Bovine $\mathrm{GH}$ was coding by gene at position of chromosome 19 (Hediger et al., 1990). Sequencing on bovine GH gene is conducted in 1980s, and it showed contained $1800 \mathrm{bp}$ with 5 exons separated by 4 introns (Woychick et al., 1982; Gordon et al., 1983).

Polymorphism of bovine GH gene was first found in 1991 and occur in exon $5^{\text {th }}$ using PCR-RLLP/Alu-I, then caused appearance two GH forms (Lucy et al., 1991). Variation of this locus was caused by nucleotide substitution, namely cytosine $(\mathrm{C})$ on guanine $(\mathrm{G})$, and made series changed of amino acid from leucine (Leu): CTG (L allele) into valine (Val): GTG (V allele) in position 127 (Zhang et al., 1992).
The study previous has been found bovine GH-AluI locus from somel cattle breeds was polymorphic with $\mathrm{L}$ allele frequence higher commonly, and some cattle breeds only showed that bovine $\mathrm{GH}$ was monomorphic (Table 1).

Polymorphism of GH-AluI locus in some beef cattle breeds was found correlated with their growth characteristic. Schlee et al. $\left(1994^{\mathrm{a}}\right)$ reported that polymorphism of GHAluI locus affect $\mathrm{GH}$ concentration of male Germany Black and White cattle, male Baharian and Tyrolean Brown cattle, and male Simmental. Accordingly, male cattle GH concentration had LL genotype for three breeds was higher than LV genotype. Schlee et al. $\left(1994^{\text {b }}\right)$ reprorted that LV genotype had correlated with breeding value of gains compared to the LL or VV genotypes of male Simmental. But Hereford breed was found V 
allele had significant correlations by increased of gains from calving to 180 days of ages (Moody et al., 1996).

Explanation above indicated that $\mathrm{GH}$ gene polymorphism and their effect on growth aspect did not similarly among cattle breeds. The study was conducted to genotyping $\mathrm{GH}-$ AluI locus of Bali cattle in Pleihari, South Kalimantan.

\section{Material and Methods Blood Sample and DNA Extraction}

Blood sample was collected from 46 Bali cattle from Pleihari, South Kalimantan. The sampling of Bali cattle for research was randomly. The blood sample approximately 3 $\mathrm{ml}$ per head take from vena jugularis, was collected into $\mathrm{K}_{3}$ EDTA tube. Genomic DNA was extracted from the blood samples according Sambrook et al. (1989) and dissolved in TE solution. Quality of genomic DNA was checked by taking ratio of O.D. at 260 and $280 \mathrm{~nm}$ in the spectrophotometer. The samples having O.D. ratio between 1.6 to 2.2 were considered to be of good quality and used for PCR study. The quantity of DNA was estimated by spectrophotometry taking O.D.260 nm.

\section{Genotyping GH-AluI Locus}

The GH-AluI locus was analysed by using PCR-RFLP method. A $211 \mathrm{bp}$ fragment of GH gene spanning from intron IV (49 bp) to exon V (162 bp) was amplified with a pair primers: GH-F: 5'GCTGCTCCTGAGGGCCCTTC-3', and GHR: 5'-CATGACCCTCA GGTACGTCTCCG3' (Reis et al., 2001). The pair primers was provided from CyberGene AB. The position of primer forward and reverse in PCR product of GH gene shown in Figure 1.

Processing of DNA amplifly was

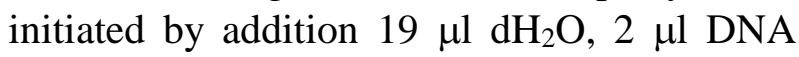
solution $( \pm 50 \mathrm{ng})$ and a pair of primer $2 \mu \mathrm{l}(16$ pmol) into tube of $0.2 \mathrm{ml}$ Ready-To-Go PCR Bead (Amersham Biosciences). PCR amplification conditions were as follow (Reis et al., 2001).: first denaturation of $95^{\circ} \mathrm{C}$ for 5 minutes, followed by 30 cycles of denaturation at $95^{\circ} \mathrm{C}$ for 30 seconds, annealing at $65^{\circ} \mathrm{C}$ for 30 seconds, extension at $72^{\circ} \mathrm{C}$ for 30 seconds, and final extension at $72^{\circ} \mathrm{C}$ for 5 minutes.

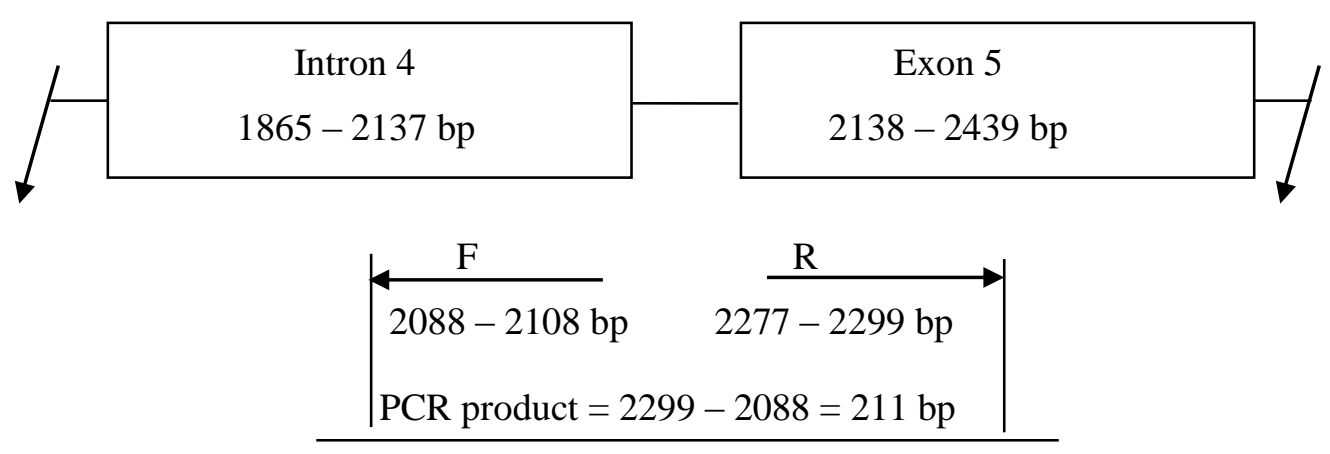

Figure 1. The position of primer forward and reverse in PCR product of GH gene

The PCR product (specific DNA fragment, size $211 \mathrm{bp}$ ) was digested by $A l u-\mathrm{I}$ enzyme (Arhrobacter luteus), production of Takara Bio Inc., its sequence and cut position was 5'-AG|CT-3'. Processing of DNA digestion was initiated into eppendorf tube 1,5 $\mathrm{ml}$ to added $10 \mu \mathrm{l}$ PCR product, $2 \mu \mathrm{l} 10 \mathrm{X} \mathrm{L}$ bufer and $0,5 \mu \mathrm{l} A l u \mathrm{I}$ enzyme (10 unit/ $\mu \mathrm{l})$, then to added $\mathrm{dH}_{2} \mathrm{O}$ until $20 \mu \mathrm{l}$. Incubated at $37^{\circ} \mathrm{C}$ for 2 hours. The digestion product was separated by electrophoresed in $1 \% \mathrm{w} / \mathrm{v}$ agarose gel containing of etidium bromida into TBE buffer. The digestion product of respective DNA samples was taken $5 \mu \mathrm{l}$ and mixed with $2 \mu$ l loading bufer, then pipetted into gel well. Running gel was regulated at 100 volt for 30 minutes and $100 \mathrm{bp}$ DNA ladder used to identification the size of DNA bands. The result of electrophoresis was 
examination under ultraviolet light, and followed to photo with Polaroid camera.

\section{Genotype Identification of GH-AluI Locus}

Identification of genotype was done by comparison pattern of electrophoretic bands each sample on DNA marker band (DirectLoad $^{\mathrm{TM}}$ Wide Range DNA Marker, Sigma Production). The VV genotype of bovine GH-AluI locus was appeared by existed of one band: $211 \mathrm{bp}, \mathrm{LV}$ genotype by three

$$
\mathrm{X}_{\mathrm{i}}=\left(2 \mathrm{n}_{\mathrm{ii}}+\Sigma \mathrm{n}_{\mathrm{ij}}\right) /(2 \mathrm{n})
$$

bands: $211 \mathrm{bp}, 159 \mathrm{bp}$ and $52 \mathrm{bp}$; and LL genotype by two bands: 159 bp and 52 bp (Reis et al., 2001).

\section{Data Analysis}

PCR-RFLP data was analysed by genotype and allele frequency (Nei and Kumar, 2000). The genotype and allele frequency was calculated by formula as:

$$
\mathrm{X}_{\mathrm{ii}}=\mathrm{n}_{\mathrm{ii}} / \mathrm{n}
$$

Where, $X_{i}$ is the $i$ allele frequency, $X_{i i}$ is the ii genotype frequency, $n_{i i}$ is the number of cattle with the genotype of $\mathrm{ii}, \mathrm{n}_{\mathrm{ij}}$ is the number of cattle with the genotype of $\mathrm{ij}, \mathrm{n}$ is the total number of Bali cattle tested.

\section{Result and Discussion}

\section{GH-AluI Genotype}

Specific DNA fragment in size of $211 \mathrm{bp}$ spanned from the forth intron region $(49 \mathrm{bp})$ to fifth of exon (162 bp) of $\mathrm{GH}$ gene containing of polimorfic region (Lucy et al., 1991), had been amplified from genomic DNA of Bali cattle by using a pair of primers: GH-F dan GH-R. The visualization of amplification GH gene $(211 \mathrm{bp})$ of Bali cattle using agarose gel $1.5 \%$, and the position of primer forward and reverses in sequence product and the mutation position in 2141 bp (GenBank: M57764) can be seen in Figure 2 and 3, respectively.

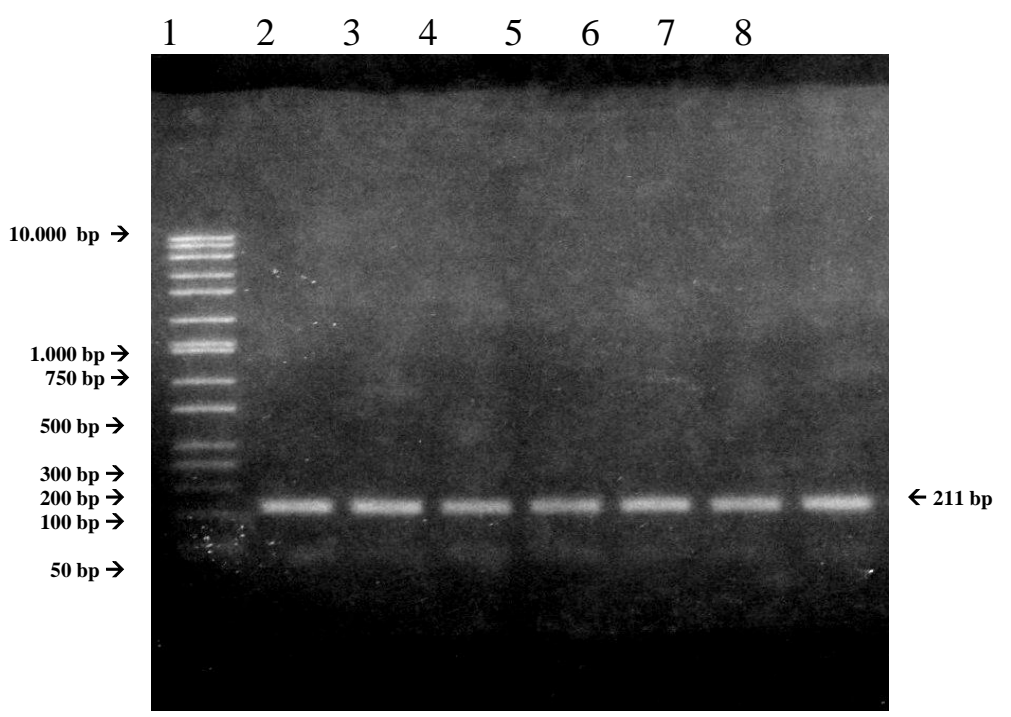

Figure 2. The visualization of amplification GH gene (211 bp) Bali cattle using agarose gel 1.5\% (M: marker 100 bp, $2-11$ research sampel. 


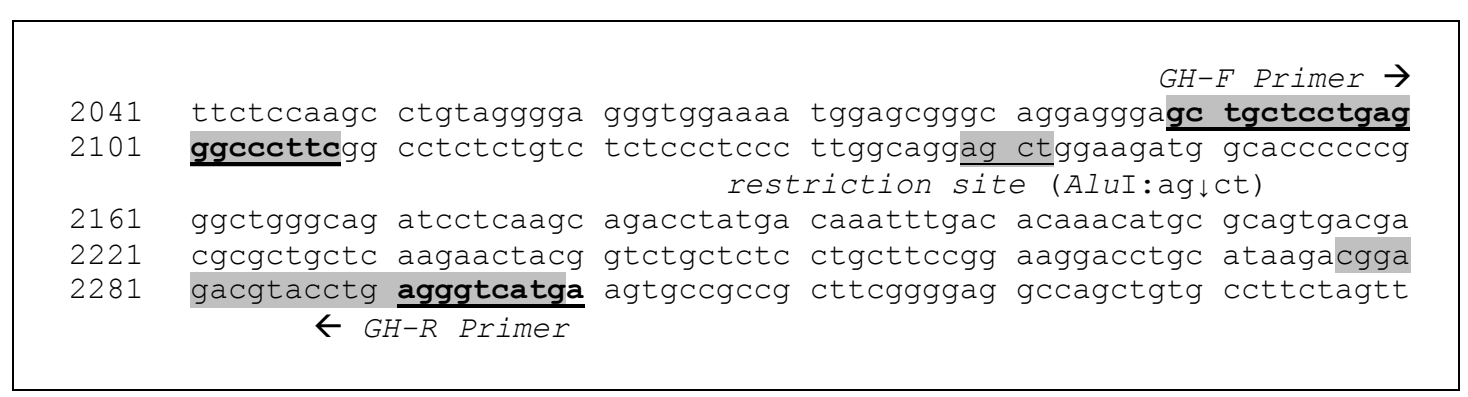

Figure 3. The position of primer forward and reverses in sequence product and the mutation position in $2141 \mathrm{bp}$ (GenBank: M57764).

The result digestion with AluI enzyme on PCR product (amplicon, size $211 \mathrm{bp}$ ) of all samples was found only one allele, namely $\mathrm{L}$ allele, while $\mathrm{V}$ allele and other allele did not found. This study, L allele was showed by successful AluI enzyme (5'-AG|CT-3') found sequence was recognized of PCR product and successful to cut PCR product into two DNA fragment with size of $159 \mathrm{bp}$ and $52 \mathrm{bp}$. According to Gordon et al. (1983) and Lucy et al. (1991), the successfully AluI enzyme was found sequence recognized on along specific DNA fragment caused by sequence which to take the cut did not mutation (taken by nucleotide $\mathrm{C}$ ), so that codon triplet serial was amino acid of leucine (Leu): CTG in position
127 of $\mathrm{GH}$ polypeptide sequence. On the contrary, $\mathrm{V}$ allele showed by failure of AluI enzyme found these sequence, so that fail to cut PCR product. Consequence, the size of PCR product before and after digestion with AluI was similarly, namely $211 \mathrm{bp}$. The failure $A l u \mathrm{I}$ enzyme found these sequence recognize caused by point which enzyme cutting was existed point mutation of nucleotide $C$ into nucleotide $\mathrm{G}$, so that cutting sequence changed from AGCT into AGGT. This point mutation caused change triplet codon series, namely CTG (Leu) change into GTG (Val) in position 127 of GH polypeptide sequence. However, V allele not found in Bali cattle population.

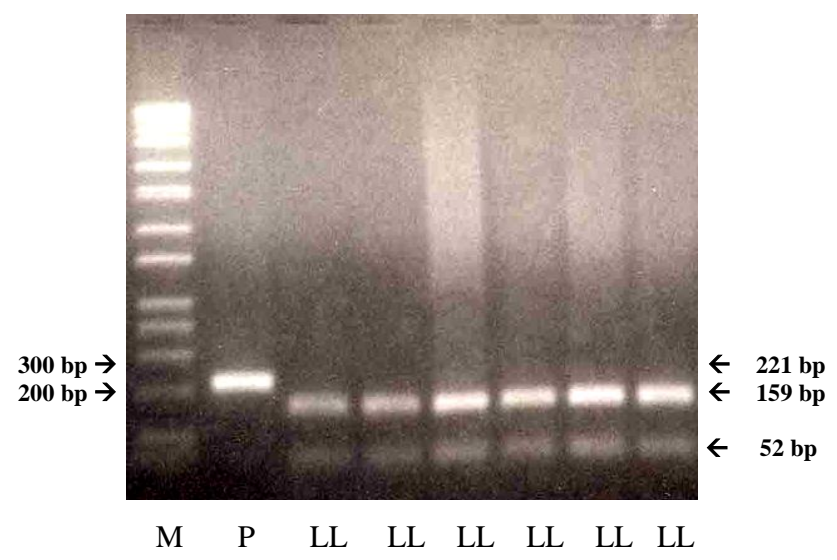

Figure 4. RFLPs of GH-AluI locus of Bali cattle in South Kalimantan. Lane 1 is 100 bp DNA ladder $(\mathrm{M})$; lane 2 is $\mathrm{PCR}$ product $(\mathrm{P}=211 \mathrm{bp})$; lane 3 until 8 are LL genotype (159 bp dan 52 bp).

The formation of DNA was double helix (diploid: 2N). If AluI enzyme found sequence recognized in both helix of DNA, and both helix of DNA was cut into two L allele, then this individu was grouped into LL genotype. If AluI enzyme only found sequence recognized in one of two helix of DNA in PCR product, then only one helix of DNA was cut, and resulted one $\mathrm{L}$ allele and one $\mathrm{V}$ allele. This individu was grouped into LV genotype. If AluI enzyme did not found sequence recognized in both helix of DNA at PCR 
product, then double helix of DNA did not cut. Therefore digesting PCR product resulted two $\mathrm{V}$ allele, and this individu was grouped into VV genotype. In this research, both genotypes: LV and VV, did not found in Bali cattle from Pleihari, South Kalimantan. Figure 4 showed genotype recognized in Bali cattle in Pleihari, South Kalimantan.

\section{Alel dan Genotype Frequency}

Frequency calculation of allele and genotype of GH-AluI locus from 46 samples of Bali cattle in Pleihari, South Kalimantan according Nei and Kumar (2000). GH-AluI locus of Bali cattle in this study only found one allele, namely $\mathrm{L}$ allele, and not found $\mathrm{V}$ allele or other allele. Therefore, GH gene found $100 \%$ has LL genotypes (Figure 4). The result indicated that $\mathrm{GH}-\mathrm{AluI}$ locus of Bali cattle (Bos sondaicus) was monomorphic. Therefore, GH-AluI locus polymorphic commonly found in European cattle (Bos taurus) and their crossing, not found in Bali cattle from Pleihari, South Kalimantan. Jakaria and Noor (2011) also found that Bali cattle from Bali island has one genotype (LL genotype, monomorphic), where Bali cattle originating from Lombok island has two genotypes (polymorphic), namely LL and VV genotype. The $\mathrm{L}$ and $\mathrm{V}$ allele frequencies from Bali and Lombok island where 1.00 and 0.00;
0.99 and 0.01 , respectively. Allele frequency distribution of $\mathrm{GH}-\mathrm{AluI}$ locus in some cattle breeds shown in Table 1.

The GH-AluI locus monomorphic also found on Tharparkar cattle, with predominance of LL genotype (Biswas et al., 2003). Some breeds of cattle as Bos indicus also had GHAluI locus were monomorphic, as found on Nelore (Ongole), Gyr, and Guzerath cattle breed (Vasconcellos et al., 2003). Monomorphic of GH-AluI locus of Bali cattle in Pleihari, South Kalimantan and in Bali island as reported by Jakaria and Noor (2011) indicated that as long as GH-AluI locus of Bali cattle population never mutation and never contaminated by gene migration from other breeds. By neglected assumption gene mutation in future, that GH-AluI locus which monomorphic of Bali cattle in Pleihari as well as Bali cattle in Bali island also usable as one of indicator to investigate crossing of Bali cattle with other breeds in certain region, especially with Bos taurus.

\section{Conclusion}

GH-AluI locus was found monomorphic in Bali cattle from Pleihari, South Kalimantan. Hhowever, it usable as one of indicator for detecting purebreed of Bali cattle in certain region.

Table 1. Allele frequency distribution of GH-AluI locus in Bos taurus, Bos indicus and Bos sondaicus

\begin{tabular}{|c|c|c|c|c|}
\hline \multirow{2}{*}{ Cattle Breed } & \multirow{2}{*}{$\mathrm{N}$} & \multicolumn{2}{|c|}{ Alel } & \multirow{2}{*}{ Source } \\
\hline & & $\mathrm{L}$ & $\mathrm{V}$ & \\
\hline Bali cattle (in Pleihari) & 46 & 1,0000 & 0,0000 & Result in this study \\
\hline Bali cattle (in Bali island) & 200 & 1.0000 & 0.0000 & Jakaria \& Noor, 2011 \\
\hline Nellore & 63 & 1,0000 & 0,0000 & Vasconcellos et al., 2003 \\
\hline Nellore & 79 & 1.0000 & 0.0000 & Curi et al., 1006. \\
\hline Guzerath & 25 & 1,0000 & 0,0000 & Vasconcellos et al., 2003 \\
\hline Brahman & 324 & 1.0000 & 0.0000 & Beauchemin et al., 2006. \\
\hline Madura & 65 & 1,0000 & 0,0000 & Hartatik et al., 2012. \\
\hline Gyr & 83 & 1,0000 & 0,0000 & Vasconcellos et al., 2003 \\
\hline West Sumatera Pesisir & 134 & 0.9920 & 0.0080 & Jakaria et al., 2007. \\
\hline Peranakan Ongole (PO) & 52 & 0,9800 & 0,0200 & Hartatik et al., 2012. \\
\hline $\begin{array}{l}\text { Bali cattle (in Lombok } \\
\text { island) }\end{array}$ & 32 & 0.9700 & 0.030 & Jakaria \& Noor, 2011 \\
\hline Santa Gertrudis & 20 & 0,9700 & 0,0300 & Vasconcellos et al., 2003 \\
\hline Holstein (pejantan) & 70 & 0,9600 & 0,0400 & Lucy et al., 1993 \\
\hline Mertolenga & 22 & 0,9550 & 0,0450 & Reis et al., 2001 \\
\hline $\begin{array}{l}\text { Karan Fries (Holstein } \\
\text { FriesianxTharparkar) }\end{array}$ & 26 & 0,9400 & 0,0600 & Pal et al., 2004 \\
\hline Mirandesa & 21 & 0,9285 & 0,0715 & Reis et al., 2001 \\
\hline Nellore & 211 & 0,9200 & 0,0800 & Unanian, et al., 2000 \\
\hline
\end{tabular}




\begin{tabular}{|c|c|c|c|c|}
\hline \multirow{2}{*}{ Cattle Breed } & \multirow{2}{*}{$\mathrm{N}$} & \multicolumn{2}{|c|}{ Alel } & \multirow{2}{*}{ Source } \\
\hline & & $\mathrm{L}$ & V & \\
\hline Limmousine x Madura & 81 & 0,9100 & 0,0900 & Hartatik et al., 2012. \\
\hline Mazandrani & 97 & 0.9100 & 0.0900 & Zakezadeh et al., 2006 \\
\hline Benggala & 115 & 0,9000 & 0,1000 & Sutarno, 2004 \\
\hline Canchim & 30 & 0,9000 & 0,1000 & Vasconcellos et al., 2003 \\
\hline $\begin{array}{l}\text { Canchim }(62,5 \% \text { Charolais } \\
+37,5 \% \text { Zebu) }\end{array}$ & 329 & 0,9000 & 0,1000 & Pereira et al., 2005 \\
\hline Baharian \& Tyrolean Brown & 20 & 0,9000 & 0,1000 & Schlee et al., $1994^{\mathrm{b}}$ \\
\hline Limmousine $\mathrm{x} P \mathrm{PO}$ & 56 & 0,8900 & 0,1100 & Hartatik et al., 2012. \\
\hline Marinhoa & 32 & 0,8750 & 0,1250 & Reis et al., 2001 \\
\hline Holstein (induk) & 142 & 0,8700 & 0,1300 & Kratochvilova et al.,2000 \\
\hline Alentejana & 22 & 0,8640 & 0,1360 & Reis et al., 2001 \\
\hline $\begin{array}{l}\text { Canchim }(65,7 \% \text { Charolais } \\
+34,3 \% \text { Zebu) }\end{array}$ & 359 & 0,8500 & 0,1500 & Pereira et al., 2005 \\
\hline Simmental & 52 & 0,8200 & 0,1800 & Regitano et al., 2000 \\
\hline Caracu & 30 & 0,8000 & 0,2000 & Vasconcellos et al., 2003 \\
\hline German Black \& White & 23 & 0,8000 & 0,2000 & Schlee et al., $1994^{\mathrm{b}}$ \\
\hline Angus & 527 & 0,7700 & 0,2300 & Barendse et al. (2006) \\
\hline Aberdeen Angus & 52 & 0,7700 & 0,2300 & Vasconcellos et al., 2003 \\
\hline Shorthorn & 500 & 0,7600 & 0,2400 & Barendse et al., 2006 \\
\hline Preta & 27 & 0,7595 & 0,2405 & Reis et al., 2001 \\
\hline Charolais & 36 & 0,7400 & 0,2600 & Regitano et al., 2000 \\
\hline Charolais & 30 & 0,7200 & 0,2800 & $\begin{array}{l}\text { Garcia, } 2001 \text { dalam Vasconcellos et } \\
\text { al., } 2003\end{array}$ \\
\hline Simmental & 41 & 0,7100 & 0,2900 & Schlee et al., $1994^{\mathrm{b}}$ \\
\hline Arouquesa & 24 & 0,7085 & 0,2915 & Reis et al., 2001 \\
\hline Polish Friesian & 214 & 0,6900 & 0,3100 & Grochowska et al., 2001 ${ }^{\mathrm{b}}$ \\
\hline Limousine & 130 & 0,6730 & 0,3270 & Dybus, et al., 2003 \\
\hline Polish Friesian (bulls) & 155 & 0,6500 & 0,3500 & Oprzadek et al., 2005 \\
\hline Barros & 23 & 0,5870 & 0,4130 & Reis et al., 2001 \\
\hline Maronesa & 24 & 0,3960 & 0,6040 & Reis et al., 2001 \\
\hline
\end{tabular}

Keterangan: $\mathrm{L}=$ Leu (asam amino leucine); $\mathrm{V}=$ Val (asam amino valine)

\section{Reference}

Barendse, W., R.J. Bunch, B.E. Harrison and M.B. Thomas. 2006. The Growth Hormone GH1:c457C $>\mathrm{G}$ Mutation is Associated with Intramuscular and Rump Fat Distribution in Large Sample of Australian Feedlot Cattle. Anim. Genet. 37:211-214.

Beauchemin, Evaluation of DNA Polymorphisms involving Growth Hormone Relative to Growth and Carcass Characteristics in Brahman Steers. Genet. Mol. Res. 5(3):438-447.

Biswas, T.K., T.K. Bhattacharya, A.D. Narayan, S. Badola, P. Kumar and A. Sharma, 2003. Growth Hormone Gene Polymorphisme and Its Effect om Birth
Weight in Cattle and Buffalo. AsianAust. J. Anim. Sci. 16(4):494-497.

Curi, R.A., H.N. Oliveira, A.C. Silveira and C.R. Lopes. 2005. Association Between IGF-I, IGF-IR and GHRH gene Polymorphism and Growth and Carcass Traits in Beef Cattle. Livestock Production Science, 94(3): 159-167.

Dybus, A., M. Kmiece, Z. Sobek and B. Winiewski. 2003. Associations between Polymorphism of the Growth Hormone Gene and Production Traits of Limousine Cattle. Available at: http://www.medwet.lublin.pl/Year\%202 0 03/Vol03-02/art185-02.htm. Accesion date: $10 / 21 / 05$

Gordon, D.F., D.P. Quick, C.R. Erwin, J.E. Donelson and R.A. Maurer, 1983. 
Nucleotide Sequence of the Bovine Growth Hormone Chromosomal Gene. Molecular and Cellular Endocrinology 33(1): 81-95.

Grochowska,R.,

P.Sorensen,

L.Zwierzchowski, M.Snochowski and P.Lovendah, 2001. Genetic Variation in Stimulated GH Release and in IGF-I of Young Dairy Cattle and Their Associations with the Leu/Val Polymorphism in the GH Gene. J. Anim. Sci 79: 450-476.

Hartatik, T., S.. Volkandari, M.P. Rachman, and Sumadi, 2012. Polymorphism Leu/Val of Growth Hormone Gene Identified from Limmousine Cross Local Cattle in Indonesia. Sustainable Future for Human Security (SUSTAIN).

Hediger, R., S.E. Johnson, W. Barendse, R.E. Drinkwater, S.S. Moore and J. Hetzel, 1990. Assigment of the GH gene locus to $19 \mathrm{q} 26 \mathrm{qter}$ in cattle and to $11 \mathrm{q} 25 \mathrm{qter}$ in sheep by in situ hybridization. Genomics 8:171-174.

Jakaria, D. Duryadi, R.R. Noor, B. Tappa and H. Martojo. 2007. Evaluasi Keragaman Genetik Gen Hormon Pertumbuhan Sapi Pesisir Sumatera Barat Menggunakan Penciri PCR-RFLP. Media Peternakan 30: 1-10.

Jakaria and R.R. Noor, 2011. Analysis on AluI Growth Hormone $\left(\mathrm{GH}^{A l u-\mathrm{I}}\right)$ Gene in Bali Cattle. J. Indonesian Trop. Anim. Agric. 36(2):77-82.

Kratochvilova, M., F. Nespor and F. Urban. 2000. AluI Growth Hormone Gene Polymorphism, Lifetime Growth Parameters and Milk Production in Holstein Cattle. 51 ${ }^{\text {st }}$ Annual Metteng of the European Association for Animal Production, The Hague, The Netherlands.

Lucy, M.C., S.D. Hauser, P.J. Eppard, G.G. Krivi and R.J. Collier, 1991. Genetic Polymorphism within the Bovine Somatotropin (bST) Gene Detected by Polymerase Chain Reaction and Endonuclease Digestion. J. Dairy Sci. 74 (Suppl.1):284 (Abstr.).
Lucy, M.C., S.D. Hauser, P.J. Eppard, G.G. Krivi, J.H. Clark, D.E. Bauman and R.J. Collier, 1993. Variants of Somatotropin in Cattle: Gene Frequencies in Major Dairy Breeds and Associated Milk Production. Domest Anim Endocrinol. Oct; 10(4) : 325-333.

Moody, D.E., D. Pomp, S. Newman and M.D. MacNeil, 1996. Characterization of DNA Polymorphism in Three Populations of Hereford Cattle and Their Associations with Growth and Maternal EPD in Line 1 Hereford. J. Anim. Sci. 74:1784-1793.

Nei, M. and D. Kumar. 2000. Molecuar evolution and phylogenetics. Oxford University Press, New York.

Oprzadek, J., K. Flisikowski, L. Zwierchowski, E. Juszczuk-Kubiak, S. Rosochacki and E. Dymnicki. 2005. Association between Polymorphism of Some Candidate Genes and Growth Rates, Feed Intake and Utilisation, Slaughter Indicator and Meat Quality in Cattle. Archiv Fur Tierzucht, 48 (special issue): 81-87.

Pal, A., A.K. Chakravarty, T.K. Bhattacharya, B.K. Joshi and A. Sharma. 2004. Detection of Polymorphism of Growth Hormone Gene for the Analysis of Relationship between Allele Type and Growth Traits in Karan Fries cattle. Asian-Aust.J.Anim. Sci., Vol. 17, No.10 : 1334-1337.

Pereira, A.P., M.M. de Alencar, H.N. de Oliveira and L.C. de Almeida Regitano. 2005. Association of GH and IGF-1 Polymorphism with Growth Traits in a Synthetic Beef Cattle Breed. Genet. Mol. Biol. Vol.28 No.2.

Reis, C., D. Navas, M. Pereira and A. Cravador, 2001. Growth Hormone AluI Polymorphism Analysis in Eight Portuguese Bovine Breeds. Arch. Zootec. 50:41-48.

Sambrook, J., Fritcsh and T. Maniatis, 1989. Molecular Cloning Laboratory Manual. Second Edition, Vol. 3. Cold Spring Harbor Laboratory Press. USA.

Schlee, P., R. Graml, E. Schallenberger, D. Schams, O.Rottmann, A. Olbrich-Bludau 
and F. Pirchner, 1994 ${ }^{\mathrm{a}}$. Growth Hormone and Insulin-like Growth Factor I Concentrations in Bulls of Various Growth Hormone Genotypes. Theor Appl Genet 88 : 497-500.

Schlee, P., R. Graml, O. Rottmann and F. Pirchner, $1994^{\mathrm{b}}$. Influence of Growth Hormone Genotypes on Breeding Values of Simmental Bulls. J. Anim Breed Genet 111:253-256.

Sutarno. 2004. Penyulihan Asam Amino Leucin oleh Valin pada Posisi 127 Gen Penyandi Hormon Pertumbuhan dan Pengaruhnya terhadap Pertumbuhan Sapi Benggala. J. Veteriner 5(1).

Unanian, M.M., C.C. Barreto, A.R. Freitas, C.M.T. Cordeiro and L.A. Josahkian. 2000. Associacao so Polimorfismo do Gene do Hormonio de Crescimentocom a Carateristica Peso em Bovinos da Raca Nelore. (Association between Growth Hormone Gene Polymorphism and Weight Traits in Nellore Bovines) In: Brasil Language; Abstract: In English. Rev. Bras. Zootec. 29 (5):1380-1386.

Vasconcellos L.P.M.K., D.T. Talhari, A.P. Pereira, L.L. Coutinho, L.C.A. Regitano,
2003. Genetic Characterization of Aberdeen Angus Cattle Using Molecular Markers. Available at: http://www.scielo.br/scielo.php?script=s ci_arttex\&pid=S1415-4572003 000200005\&Ing=en \&nrm =iso. Accession date: 12/19/03.

Woychick, R.P., S.A. Camper, R.H. Lyons, S. Horowitz, E.C. Goodwin and F.M. Rottman, 1982. Cloning and Nucleotide Sequencing of the Bovine Growth Hormone Gene. Nucleic Acids Research, Vol. 10, Issue 22 7197-7210.

Zakezadeh, S., G. Rahimi, S.R. MiraeAshtiani, A. Nejati-Javaremi, M. Moradi-Shahrbabak, P. Reineeke, M. Reissmann, A.A. Masoudi, C. Amirinia and S.A. Mirhadi. 2006. Analysis of Bovine Growth Hormone Gene Polymorphism in Three Iranian Native Breeds and Holstein Cattle by RFLPPCR. Biotech. 5:385-390.

Zhang, H.K., K.C. Maddock, D.R. Brown, S.K. DeNise and R.L. Ax., 1992. Bovine Growth Hormone Gene Frequencies in Samples of U.S. AI Bulls. J. Anim. Sci. 71 (Suppl.1):93 (Abstr.). 